\title{
TITLE:
}

\section{Antidegenerative effects of partial disc replacement in an animal surgery model(Abstract_要旨 )}

\author{
AUTHOR(S): \\ So, Kazutaka
}

\section{CITATION:}

So, Kazutaka. Antidegenerative effects of partial disc replacement in an animal surgery model. 京都大学, 2007, 博士(医学)

ISSUE DATE:

2007-03-23

URL:

http://hdl.handle.net/2433/135689

RIGHT: 


\begin{tabular}{|c|c|}
\hline 名 & $\begin{array}{lll}\text { 穼う } & \text { かず } & \text { 路 } \\
\text { 和 } & \text { 隆 }\end{array}$ \\
\hline 学位 (専攻分野) & 博 士（医 学） \\
\hline 学位記番号 & 医 博 第 3069 号 \\
\hline 学位授与の日付 & 平成 19 年 3 月 23 日 \\
\hline 学位授与の要件 & 学位規則第 4 条第 1 項 該 当 \\
\hline 研究科・専攻 & 医 学 研 究 科 外 科 系 専 攻 \\
\hline 学位論文題目 & $\begin{array}{l}\text { Antidegenerative effects of partial disc replacement in an animal } \\
\text { surgery model } \\
\quad \text { (動物実験モデルに拀ける, 椎間板部分置換術による変性遅延効果について) }\end{array}$ \\
\hline
\end{tabular}

\section{論文 内容の 要旨}

腰椎椎間板の変性は腰痛の原因になりうるが，現行の手術治療で得られる効果には限界がある。最近注目されている椎間 板部分置換術（partial disc replacement，以下 PDR）は，変性した髄核を弾力性のあるインプラントで置換することで椎 間板高を維持し，椎間板性腰痛を和らげ，変性の進行を予防するといわれている。一部の外国では既に治験が行われている が，その治療効果を示せた動物実験はこれまでに無かった。これは瀻細な手術手技が要求されることや，インプラントが椎 間板内から脱転しやすいことなどのために，動物実験では有意義な評価をすることが難しかったためと考えられるが，本研 究では脱転を起こさないPDRの動物実験モデルを作成し，その治療効果を定量的に評価することができた。

インプラントは，ポリビニルアルコール（以下 PVA，平均分子量 $8800 ，$ 含水率 30 ～ $40 \%$ ）を原料とし，径約 $1.9 \mathrm{~mm}$ ，長 さ約 $20 \mathrm{~mm}$ の丸鉛筆型に加工して用いた。日本白色家鬼30羽の腰椎椎間板（L2/3，3/4）に対して sham, control, PVA の内いずれか 2 つの手術を全身麻酔下に行った。椎間板へのアプローチのみを行う手術を sham，アプローチ後椎間板に径 $2 \mathrm{~mm}$ の Kirschner wire で貫通孔を作成し，変性をおこさせる手術を control とした。さらに Kirschner wireで作成した孔 にインプラントを挿入し，椎間板を貫通させた状態で留置する手術をPVA（PDR モデル）とした。動物は術後 $1 ， 3 ， 6$ ケ月のいずれかで安楽死させ，採取した椎間板（sham 群15，control 群15，PVA 群30椎間板）に対してレントゲン的，組 織学的評価を行った。

術前および屠殺時にレントゲン透視撮影を行い，両時点での椎間板高（disc height index，以下 DHI）を算出し，\% DHI（=屠殺時 DHI $\div$ 術前 DHI×100）により椎間板高の変化を評価した。また各術後時期の PVA 群の中から，2つずつ 計 6 椎間板を無作為に選出し，そのインプラントを摘出して実体顕微鏡で変形，破損状況について観察した。それ以外の全 ての標本は正中面での薄切切片を組織観察し, 線維輪の变性度を 5 段階評価した（変性度 $0:$ 変性なし〜変性度 $4:$ 高度の 変性)。

神経損傷，深部感染，インプラント脱転例はなかった。レントゲン的には PVA 群の％DHI は control 群のそれより有意 に高い值を示し，sham 群と同等であった。組織学的には sham 群の線維輪の変性は術後 6 ケ月でもわずかであったが, control 群では術後 1 ケ月から線維輪全体に強い変性を呈していた。PVA 群では術後早期には線維輪の変性は中央部に限局 していたが，術後長期には辺縁部に向けて変性が拡大していく傾向があった。PVA 群の変性度は常に control 群より有意 に低かったが，sham 群よりは高い傾向にあり，術後６ヶ月においてのみ sham 群との有意差を認めた。実体顕微鏡観察で インプラントの扁平化を椎間板内に認めたが，破損しているものはなかった。

本論文中の手術モデルは椎間板貫通型のインプラントを用いるなど臨床的には一般的でない点があったが，脱転を完全に 防ぎ，椎間板高保持効果も十分に得られたという点では優れた実験モデルであった。そしてPDRには，線維輪の変性の進 行を抑制する効果があることも組織学的に証明できた。PVA は，製法によって含水率とともに弾性率，耐摩耗性などの性 質を制御できる。より効果的にPDR を行うためには，材料を選別することが今後必要であると考えられた。 
腰椎椎間板の变性は腰下肢痛の原因になるが, 䯣核切除術や脊椎固定術で得られる効果には限界がある。椎間板部分置換 術（PDR）は椎間板性腰痛を和らげ, 変性の進行を予防するといわれている。しかしこの手術はインプラントが脱転しや すいこともあり, その治療効果を示せた動物実験はこれまでに無かった。本研究ではPDRのウサギ動物実験モデルを作成 し，その治療効果をレントゲン的，組織学的に評価した。また比較のため，变性モデル手術，sham 手術を行った。

PDR モデル手術では，ポリビニルアルコール製の椎間板貫通型インプラントを用いて，側方から挿入したところ，イン プラントの脱転を防止しえた。術後 6 ケ月までの観察では, 椎間板高は変性モデル手術後と比べて有意に高く維持され, sham 手術後とほぼ同等であった。組織学的には変性モデル手術後と比べて線維輪の変性度は有意に抑制されていることが 示された。また，インプラントに亀裂，破損は見当たらなかった。

以上の研究は, PDRの実験モデルを確立し, その治療効果について評価しえた点で意義梁く, 今後の PDRの進展に大 きく貢献するものと考えられる。

したがって，本論分は博士（医学）の学位論文として価值あるものと認める。

なお，本学位授与申請者は，平成19年 1 月 26 日実施の論文内容とそれに関した諮問を受け，合格と認められたものである。 